\title{
Reactions to Oppression: Jurisgenesis in the Jurispathic State
}

\author{
John Valery White
}

If there existed two legal orders with identical legal precepts and identical, predictable patterns of public force, they would nonetheless differ essentially in meaning if, in one of the orders, the precepts were universally venerated while in the other they were regarded by many as fundamentally unjust. ${ }^{1}$

-Robert Cover

\section{INTRODUCTION}

Traditional jurisprudence has been criticized for conceiving as homogeneous the world in which law operates. ${ }^{2}$ According to this criticism, traditional jurisprudence assumes that democratic representation, ${ }^{3}$ majoritarian consensus, ${ }^{4}$ and principled decisions necessarily create a neutral and just order. ${ }^{5}$

Many scholars have argued that the world in which law operates is not homogeneous and that the assumptions underlying traditional jurisprudence are therefore invalid. ${ }^{6}$ Some of these scholars suggest that the application of traditional jurisprudential frameworks to situations involving people of color is unjust because the views of people of color have not been incorporated in

1. Cover, The Supreme Court, 1982 Term-Foreword: Nomos and Narrative, 97 HaRv. L. REv. 4, 7 (1983) (footnote omitted).

2. This criticism is implicit in intellectual inferiority and meritocracy standards arguments. See Kennedy, Racial Critiques of Legal Academia, 102 HARV. L. REV. 1745, 1751-54 (1989) (discussing intellectual inferiority theories as basis for emerging racial critiques).

3. See R. WOLFF, IN DEFENSE OF ANARCHISM (2d ed. 1976) (questioning legitizacy of democratic representation).

4. See generally A. BICKel, THE Least Dangerous BRANCh: THE SUPREME COURT AT THE BaR OF POLITCS 16-23 (1962) (discussing countermajoritarian difficulty).

5. See Wechsler, Toward Neutral Principles of Constitutional Law, 73 HARV. L. REV. 1 (1959).

6. The Critical Legal Studies Movement (CLS), feminist jurisprudence, and Critical Race Theory make such claims. This Note will focus on the latter movement. See generally Matsuda, When the First Quail Calls: Multiple Consciousness as Jurisprudential Method, 11 WOMEN's RTS. L. REP. 7 (1989) (students of color forced to deny personal experiences to apply traditional standards).

For a definition of who are critical race theorists see Peller, Race Consciousness, 1990 DURE L.J. 758, 759 \& n.6 (including Professors Mari Matsuda, Derrick Bell, Richard Delgado, and Patricia Williams); see also Johnson, The New Voice of Color, 100 Y ALE L.J. 2006 (1991) (including as critical race theorists Black professors who are critical of voice-of-color concept); Kennedy, $A$ Cultural Pluralist Case For Affirmative Action in Legal Academia, 1990 DUKE L.J. 705, 706 \& nn.4-5 (Duncan Kennedy). 
that jurisprudence. ${ }^{7}$ They contend that traditional jurisprudence is neither neutral $^{8}$ nor legitimate and imposes not justice, but power. ${ }^{9}$

In support of their criticisms of traditional jurisprudence, some scholars of color have begun to develop a jurisprudence that examines law, liberation, and justice within the context of racial oppression. Based on the experiences of "oppressed communities," the work of these scholars professes to offer a conception of the law that captures oppressed communities alternative views of law, liberation, and justice. ${ }^{10}$

This alternative jurisprudence's primary problem is that in attempting to emphasize the unity of the oppressed communities' perspective, it often inaccurately reflects the diverse viewpoints of the communities. ${ }^{11}$ While a jurisprudence reflecting the views of oppressed people is both valuable and necessary, if it is inaccurate, misleading, or if it espouses only the views of oppressed communities' elites, it marginalizes the oppressed at least as much as traditional jurisprudence does.

This Note offers a model for analyzing the political and legal traditions of oppressed communities and developing a jurisprudence that accurately reflects the communities' views. ${ }^{12}$ Under this model, each of these diverse views can be understood from one of four perspectives: parochialism, fatalism, neo-liberalism, and individualism. These four perspectives are defined by an oppressed community's members' aspirations for liberation. Different ideals of justice and liberation underlie each perspective. Though touching on some of the communities' sentiments, the examinations of scholars of color have thus far been largely piecemeal, overemphasizing certain views, unwittingly combining divergent views, or marginalizing and dismissing unpopular views. ${ }^{13}$

7. See, e.g., Delgado, The Imperial Scholar: Reflections on a Review of Civil Rights Literature, 132 U. PA. L. REV. 561 (1984).

8. Alternative jurisprudence is antineutral. See Kennedy, supra note 2, at 1746, 1760-87 (racial distinctiveness theses of Derrick Bell, Richard Delgado, and Mari Matsuda).

9. See, e.g., Delgado, Storytelling for Oppositionists and Others: A Plea For Narrative, 87 MICH. L. REV. 2411, 2413-16 (1989) (dominant group creates stories making current social arrangements seem fair and natural).

10. "[T]hose who have experienced discrimination speak with a special voice to which we should listen." Matsuda, Looking to the Bottom: Critical Legal Studies and Reparations, 22 HARV. C.R.-C.L. L. REV. 323, 324 (1987). "The strength of Critical Race Scholarship is its identification of the commonality of minority experience." Espinoza, Masks and Other Disguises: Exposing Legal Academia, 103 HARV. L. REV. 1878, 1885 (1990).

11. See, e.g., Kennedy, supra note 2, at 1778-87 (Matsuda "homogenizes" oppressed communities).

12. Adopting a simplistic, bipolar conception of the oppressed community as Black people and the oppressor community as white people and the state and using examples from Black social and political history for illustration, this Note will show how the model's four perspectives view four cases with white and Black actors and victims. For the purpose of iliustration, I bracket various other community definitions that may exist, such as communities defined by class, gender, age, or national origin. Such a simplistic racial model is of limited value; however, I use it because it is familiar and retains considerable force in popular discourse. Also, the state is associated with the white community both for simplicity and because in oppressed communities the state generally has been regarded as a tool of oppressor communities.

13. Professor Stephen Carter has noted this marginalization:

[T] he different voice hypothesis is at the very least either too broad or too narrow-that is, either it sweeps under its ambit even the works of those scholars of color who would deny that their 
After defining the model, Part II argues that the four perspectives are fundamentally inconsistent with each other. It then evaluates from each perspective four similar, violative acts involving community members as victims, perpetrators, both, or neither, demonstrating each perspective's different conception of justice. To illustrate the model's value as an analytical tool, Part III analyzes two articles by scholars of color. It argues that, with an unclear or incomplete framework guiding their examination, scholars of color cloud the jurisprudence they attempt to illuminate. ${ }^{14}$

\section{THE COMMUNITY MODEL}

At times, oppressed communities seem to regard criminal law violations with clear and overt apathy. On other occasions, they call vehemently for enforcement of those same laws. In April 1989, a twenty-eight-year-old white woman was beaten and raped while jogging in northern Central Park, the result of a night of marauding by Black and Latino teenagers. ${ }^{15}$ Certainly the Black community thought the rape/assault was abhorrent; ${ }^{16}$ however, there have been recurring references among Blacks to feelings of "otherness"17 and the state's role in creating despair ${ }^{18}$ in inner-city youths; to protectionist attitudes within the community: ${ }^{19}$ and to calls for the unmerciful, immediate, and harsh state punishment of the perpetrators. ${ }^{20}$ What is the source of these apparently contradictory reactions to clear violations of fellow human beings? Is there a coherent way of understanding different reactions in African-American communities to seemingly similar cases, for example the Howard Beach killing ${ }^{21}$ versus a similar killing involving only whites? What is the nature of the variety of these responses and how are they influenced by oppression?

The following model will show that any community whose fundamental self-conception is as oppressed will not view liberation and thus life and justice

voice is different, or it in effect denies them their birthright as members of . . the non-white community.

Carter, The Best Black, And Other Tales, 1 ReConstruction No. 1, 1990, at 6, 31.

14. See, e.g., Johnson, supra note 6 (tripartite classification of critical race theorists analogous to Critical Feminist Theory: Hierarchal Majoritarianism, Monism, and emerging Nationalism) and Peller, supra note 6 (employing frame of integrationism and nationalism).

15. Pitt, Gang Attack Unusual for its Viciousness, N.Y. Times, Apr. 25, 1989, at B1, col. 2.

16. Sturz, What Kids Who Aren't Wolves Say About Wilding, N.Y. Times, May 1, 1989, at A17, col. 2 ("perpetrators should be dealt with harshly").

17. See Chace, Safety in the Park: In Women's Hands, N.Y. Times, Apr. 27, 1989, at A31, col. 1.

18. See Sturz, supra note 16.

19 "Some are so concerned to defend their community from what they see as racial slurs. ... [H]ad the victim been black, there would have been far less publicity and outrage." Chira, Rape Suspects' Neighbors Feel Accused, N.Y. Times, May 1, 1989, at Al, col, 3.

20. Sturz, supra note 16 , at A17, col. 2.

21. Patricia Williams describes the "Howard Beach case" (Black men beaten and chased into freeway by white teenagers; one Black man was killed by oncoming car) in terms of tensions between community safety and racial discrimination. Williams, Spirit-Murdering the Messenger: The Discourse of Fingerpointing as the Law's Response to Racism, 42 U. MIAMI L. REV. 127, 136-50 (1987). 
monolithicly. The model will outline the alternative ways a hypothetical oppressed community will incorporate questions of life, liberation, and justice into its jurisprudence.

\section{A. Defining the Model}

Professor Robert Cover proposed that every insular community has its own normative universe in which it develops its own, insular legal tradition; this he called jurisgenesis. ${ }^{22}$ Jurisgenesis exists independently of states and takes place through an essentially cultural medium..$^{23}$ Cover described a world in which states arise not to impose law where none existed but to suppress a plethora of competing legal traditions; he termed this the state's "jurispathic tenden$c y .{ }^{24}$ Cover's state, while it establishes law, simultaneously destroys it. ${ }^{25}$ In establishing law, Cover's state destroys legal traditions that aid daily functioning within our diverse communities. Jurisgenesis drives the development of jurisprudential perspectives in our hypothetical community.

Our hypothetical community has a heritage of oppression by other communities and the state (the historical construction). The oppressed community's basic concern, and thus the substance of its discourse, is liberation. How it intends to achieve liberation is governed by its views of the nature of oppression. Its view of justice is then determined by its plan for liberation. For our oppressed community all noncommunity members are associated with the oppressive state. ${ }^{26}$ Such a view of life creates a world of the oppressed us versus the oppressive them. All intercommunity relationships are characterized as conflict-laden and exploitative.

The community's heritage of oppression and its resulting pursuit of liberation reveal four perspectives on life which in turn guide its member's conceptions of justice. ${ }^{27}$ The four perspectives-parochialism, fatalism, neo-liberalism, and individualism-each attempt to rebel against and destroy the oppressive order while simultaneously vying for survival in the oppressive environment. ${ }^{28}$ No single perspective, of course, exists in pure form. A community member is likely to possess some combination of perspectives. The value of

22. Cover, supra note 1 , at $4-11,42$.

23. Id.

24. Id. at 40 .

25. Id. at 44 \& passim.

26. Membership in the community may be defined by the historical construction's claim over a person via a substantive element of the historical story, such as race, color, or national origin. See, e.g., Himes, A Sociological Redefinition of the American Negro Grollp, 9 PHYLON 125 (1948).

27. This Note assumes that the four perspectives exist in other communities that define themselves through quite different, but parallel, historical constructions. That is to say, the matrix that defines the four perspectives here lies within a larger, parallel matrix defining the perspectives of the larger society. As such, the oppressed community differs from the larger society essentially because of its distinct historical construction. The oppressed community survives only because of the accuracy and/or persuasiveness of the historical construction and the success of the community members in promoting that construction.

28. Cover, supra note 1 , at 9 . 
this model is that, given a particular issue, one perspective dominates a person's impressions.

The answers to two questions highlight the differences between the four perspectives. First, the community must decide whether to develop its own view of life, liberation, and justice or to simply accept the state's (society's) view. ${ }^{29}$ Second, judgments about the nature of life, liberation, and justice may be governed by material concerns rooted in the community's oppressed condition or more detached, abstract principles. ${ }^{30}$ The members of the community must decide whether they are to conduct the liberative project themselves or whether abstract or noncommunity entities such as liberal society, God, truth, or individual effort will end their community's oppressed condition.

The first perspective is insular and concerned with material improvement. Its views are closely connected to the narrative of life as oppressive. The empirical assessment behind parochialism holds the state solely responsible for the community's oppression. Its normative vision considers the prospect of liberation to be dependent upon the outcome of a combative relationship between the community and the state. Life is unjust and justice can only be won through community unity and intercommunity conflict.

The controlling ethic of parochialists is material liberation of the insular community from the state. The legal tradition of parochialism thus rejects the jurispathic state and its law. Justice requires the destruction of the oppressive law or, alternatively, the creation of an autonomous community legal system parallelling the larger system. ${ }^{31}$

29. Acceptance could be based on a theory that the state legitimately represents a consensus among competing individuals' and communities' moral constructions or that the state's view embodies a conception of objective and universal justice. The subject of inquiry here is whether justice is community-based or universal. If the community is incapable of legitimately making moral determinations, those determinations must either be made by undifferentiated individuals or an abstract order-such as natural law or the state-which transcends individuals.

30. This question is not unlike the distinction drawn by Thomas Ross between the opinions of Justices Marshall and Scalia in City of Richmond v. J.A. Croson Co., 109 S. Ct. 706 (1989): "Scalia's opinion as narrative is . . . abstract story. . . Scalia never speaks concretely about any case or context. . . . Marshall tells not only the stories of the particular dispute, but also the stories of the city . . as the capital of the Confederacy, the place of 'apartheid,' . . . with a disgraceful history." Ross, The Richmond Narratives, 68 TEx. L. REV. 381, 390-91 (1989). The answer to this question implicates the degree to which a community is pessimistic or optimistic about the prospect of liberation and justice under the oppressive order.

31. Popular conceptions of the Black Panthers are consistent with this pure view. The Panthers were perceived as a guerrilla warfare unit prepared to overthrow the state if they were not allowed to govern themselves and their community autonomously. See R. BRISBANE, BLACK ACTIVISM: RACIAL REVOLUTION IN THE UNITED STATES 1954-1970, at 193-222 (1974).

A more accurate example of parochialism is the Republic of New Afrika (RNA). The RNA declared its independence from the United States on March 31, 1968. Lumumba, Short History of the U.S. War on the R.N.A., THE BLACK SCHOLAR, Jan.-Feb. 1981, at 72. In 1969, the RNA demanded $\$ 200$ billion in reparations from the United States Government and the surrender of five southern states to establish the New Afrikan Nation. R. BRISBANE, sttpra note 31, at 183. The RNA established a provincial government in exile and developed a plan to liberate the five states through electoral victories or armed struggle. Id. at 183. By 1971, the RNA fell apart after the arrest of many of its members and a shootout with police near Jackson, Mississippi. Lumumba, supra, at 73-74. 
While intuitively appealing, parochialism is not sacrosanct or universally embraced by the oppressed community. Parochialism demands violent revolt ${ }^{32}$ and autarky; accordingly, the ideology can be pessimistic and depressing, ${ }^{33}$ especially when the prospect of successful martial revolution is remote. Despite the limits of this perspective, it is influential because, among other things, it attempts to address the community's pervasive feeling of oppression. It celebrates the history of oppression, reinforcing the community's definition, and calls for solidarity and fraternity in the battered and embattled community.

The second view retains the insular understanding of parochialism but renders an escapist conclusion. ${ }^{34}$ Life, liberation, and justice all operate as functions of a higher order that governs the insular group. The community is oppressed for an abstract reason such as destiny or God's will. Normatively, liberation will be found in "truth" or some after-life; there is no need to change the present world order. Fatalism's conception of liberation is, nonetheless, still insular and maintains that the community and the state oppose each other.

For fatalism the controlling ethic is higher truth. This ethic requires rejection of earthly law, even martyrdom. ${ }^{35}$ Living by faith, death is purifying and significant because it marks the end of a long battle with the physical and passage into the proverbial promised land..$^{36}$

The appeal of fatalism is limited, though. Fatalism abandons the hope of changing the world, investing all its adherents' energies in an "otherworldly" reality. It fails to address the injustice presupposed by the community's construction of history. It does not feed mouths, nor does it necessarily free the mind. Indeed, it may prepare the mind for further bondage. Because fatalist community members live in the "real world" and fatalism operates in the "other world," fatalism cannot exist in pure form. Fatalists must construct "real world"

32. "But violence has its limitations-it can be put down with superior force." R. BRISBANE, supra note 31 , at 159. By violence, I mean more than armed rebellion; this conception of violence encompasses political and legal action. Cf. Cover, Violence and the Word, 95 YALE L.J. 1601, 1605 (1986) (recognizing violence of legal interpretive process).

33. Parochialism paints a picture of life in which the group is defined only as oppressed and downtrodden. To compensate, parochialist constructions must proffer an uplifting portrait of the prospects of liberation.

34. See, e.g., Speech by Martin Luther King, Jr., I See the Promised Land (Apr. 3, 1968), reprinted in A TESTAMENT OF HOPE: THE ESSENTIAL WRITINGS OF MARTIN LUTHER KING, JR., 1929-1968, at 279-86 (J. Washington ed. 1986). Martin Luther King, Jr. provides an example of how people and movements shift as issues change; he can be located in all four perspectives. See id. and infra note 39.

35. "Martyrs require that any future they possess will be on the terms of the law to which they are committed (God's law) ... even in the face of world-destroying pain. . . . [T] ine interpretive commitments of a community which resists official law must also be realized in the flesh, even if it be the flesh of its own adherents." Cover, supra notes 32, at 1604-05.

36. Fatalism is located in the Black church in what James Cone calls the " white lie' that Christianity is primarily concerned with an otherworldly reality." J. CONE, BLACK THEOLOGY AND BLACK POWER 121 (1969). Indeed, fatalism is most prominently exemplified in the early Black church. "Black men were expected to accept their lot in this world and if they were obedient and honest and truthful they would be rewarded in the world after death." E. FRAZIER, THE NEGRO CHURCH IN AMERICA 19 (1974 ed.) (reprinted with C. LINCOLN, THE BLACK CHURCH SINCE FRAZIER (1974)). It was not necessary to create a just world, for the world is not a place for justice. 
dogmas to link their otherworldly vision to their real world existence. Fatalism places no limit on what may constitute dogma, making the operation of fatalism in the "real world" essentially amoral. ${ }^{37}$

The third view, neo-liberalism, rejects the pessimistic and insular outlooks of both material and visionary parochialism. It accepts that the we/they construction exists; however, its normative vision suggests that liberation will be achieved through the destruction of insular communities. ${ }^{38}$ For neo-liberals, the problem with life is not necessarily oppression itself but the existence of insular communities which manifest that oppression. Neo-liberals see the community as at least partially responsible for its oppressed situation because it clings to the narrow, insular conception implicit in the we/they construction. Neo-liberalism embraces the ethic that "all [people] are created equal." Liberation will come and justice be found when people can live their lives unericumbered by labels or the interference of other individuals. ${ }^{39}$

However, the neo-liberal perspective undermines the community to the degree that it demands a world in which right and wrong are universal and objective. Its universalist view subverts the community's we/they construction. Its quest for universalism only succeeds in narrowing the definitions of communities, not eliminating them altogether. ${ }^{40}$ Its rejection of groups validates the individual's self-interested pursuits, undercutting interests of humanity generally and community interests particularly. Depriving subcommunities of their historical legitimacy, neo-liberalism embraces the existing state and oppressive society while it resists states and parochial orders generally. Hence, neo-liberalism ignores oppressors who decide against foregoing their privileged status. Neo-liberalism proves unable to change oppressive societies which undeniably

37. Fatalism remains influential, however. It makes it possible for people to survive seemingly insurmountable conditions even if it does not change "reality." As Frazier's analysis of the Negro church points out, it "turned [Black people's] minds from the sufferings and privations of this world to a world after death where the veary would find rest and the victims of injustices would be compensated." $E$. FRAZIER, supra note 36, at 50. Hence, fatalism often lends spiritual force to combined perspectives.

38. This perspective categorizes only community members, not people with a universalist vision who lack membership in or reject the existence of the community and then call for the destruction of group distinctions.

Professor Johnson's "Hierarchical Majoritarian" category resembles a neo-liberal view. Johnson, supra note 6, part I. However, I do not necessarily accept Johnson's characterization of Professors Carter and Kennedy as Hierarchical Majoritarian, nor do I consider them necessarily neo-liberal.

39. Neo-liberalism is probably best represented by the image created by Martin Luther King, Jr.'s I Have a Dream speech: "[O]ne day this nation will rise up and live out the true meaning of its creed: "We hold these truths to be self-evident; that all men are created equal.'" Speech by Martin Luther King, Jr., I Have A Dream (1963), reprinted in BLACK PROTEST THOUGHT IN THE TWENTIETH CENTURY 349 (1987). King's speech embraces the view that there are principles embodied in the Declaration of Independence which belong to humanity: they are not the U.S. government's or white people's or anyone else's-they are universal. If these principles were achieved, humanity's problems would be solved. The speech calls for the end of racial, ethnic, and religious distinctions and is ultimately optimistic about the ability of humankind to embrace these principles and resolve its problems.

40. "The liberal wants to judge a man in terms of his uniqueness and his universal humanity ... . Universalism thus goes hand in hand with individualism." R. BLAUNER, RACIAL OPPRESSION IN AMERICA 266-67 (1972), quoted in Peller, supra note 6, at 772 n.25. 
exist. It acquiesces to power; its universal morality risks embracing "might" over "right." It becomes as escapist as fatalism because it essentially relies on oppressors to end oppression.

Neo-liberalism remains a powerful perspective, however. In a jurispathic society, neo-liberalism facilitates assimilation because it tends to accept the prevailing social order as objectively "right." Furthermore, in the face of assimilationist pressures ${ }^{41}$ and unending "oppression," neo-liberalism provides hope for the future, allowing some to live without despair.

The final view, individualism, is materialistic and personalized. Like parochialists, individualists characterize life as brutal and burdensome. However, they implicitly frame the battle, not as between the community and the state, but rather between individual community members and the oppressive society. Normatively, individualists consider futile group liberation beyond limited individual emancipation. Individualism is characterized by despair; it rejects either the existence of justice or the prospect of achieving it. ${ }^{42}$ Individualism focuses on limited liberation within life's harsh constraints. ${ }^{43}$ Community liberation for the individualist is only the aggregate of successful individual liberation. ${ }^{44}$

Each individualist creates an internal system for judging life and attaining liberation. This system is accessible to others only through the individualist's outward demands for autonomy and freedom-her demands for respect. The individualist demands respect from all who will give it and respects only those individuals who demand respect. Like the individualist's view of life, this ethic of respect is brutal and violent in its operation..$^{45}$ Individualist community members are self-righteous with potentially opposing conceptions of respect,

41. Dissatisfaction, according to separatists, can be traced to the fact that in American institutional settings Blacks are forced to adopt a culture other than their own. Boxill, Self-Respect and Protest, in PHILOSOPHY BORN OF STRUGGLE: ANTHOLOGY OF AFRO-AMERICAN PHILOSOPHY FROM 1917, at 190, 202. 03 (L. Harris ed. 1983).

42. "[Moderates sayl the problems are so enormous and complicated that Negro militancy is a futile irritation ... ." B. Rustin, From Protest to Politics: The Future of the Civil Rights Movement, in THE RADICAL PAPERS 347, 353 (I. Howe ed. 1966). Convicted prisoners "do not organize force against being dragged [or beaten into] prison [indeed, they walk themselves there] because they know that if they wage this kind of battle they will lose-very possibly lose their lives." Cover, supra note 32, at 1607-08.

43. Frazier once described some Blacks as "representative of the growing number of middle-class Negroes who have a purely secular outlook on the world . . . they have neither an intellectual heritage nor a social philosophy except a crude opportunism which enables them to get by in the white man's world." E. FRAZIER, supra note 36, at 84. Individualists know all too well that this world is not their own. They respond, as Frazier's Negro does, by creating a world around themselves.

44. Since oppression targets the community as a whole, individualists cannot ignore that community. Thus, each individualist argues that she embodies the community. Acts committed upon community members are committed upon the community and therefore the individualist. Individuals have the responsibility of suffering on behalf of the community or avenging it. Cornel West identifies a similar perspective as the first and fundamental norm at the "core of the prophetic Christian gospel": the "Christian principle of the self-realization of individuality within community." C. WEST, PROPHESY DELIVERANCE! AN AFRO-AMERICAN REVOLUTIONARY CHRISTIANITY 16 (1982) (emphasis omitted).

45. Respect emerges from violence. F. FANON, THE WRETCHED OF THE EARTH 94 (1963) ("At the level of individuals, violence is a cleansing force. It frees the native from his inferiority complex and from his despair and inaction, it makes him fearless and restores his self-respect."). 
each claiming to embody the community and all pursuing self-interests under the banner of community liberation.

The appeal of this "self-help" formula for liberation is limited, particularly because all community members may not be able to liberate themselves. The ruthless emphasis on personal concerns pits community members against each other in a desperate scramble to get what pieces of the social pie are available. Replete with in-fighting, the community never truly confronts the oppressive state. ${ }^{46}$ Ironically, individualism's presupposition that everyone can liberate himself assumes that the prevailing conditions of oppression can and will be eliminated, even when created or maintained by the state. Individualism is, however, successful when every community member is not concerned with liberation. Finally, in a jurispathic state that promotes individualism and materialism, individualism is likely to prosper.

\section{B. The Legal Traditions of the Model: Evaluation of Acts}

An understanding of each perspective's particular view of justice is revealed by examining how its adherents conceive of and evaluate various acts of violation. The evaluation of acts involves two processes. First, each perspective's ethic determines how it reacts to the actor and the victim, given each perspective's empirical and normative assessment of the oppressed/oppressor conflict. This construction produces four cases: (1) "One of us did something to one of them";, ${ }^{47}$ (2) "One of them did something to one of us"; ${ }^{48}$ (3) "We did something to ourselves"; and (4) "They did something to themselves." The application of each perspective's normative view determines whether a given perspective will perceive the actor and victim within the confines of the conflict. Second, each perspective incorporates its portrayal of the actor and victim into its definition of the act. By using narrow or broad constructions of an act, each perspective's normative ethic of liberation delineates a construction of justice capable of evaluating life events which the community faces. ${ }^{49}$

\section{Parochialism and the Just Act}

Since the ethic of parochialism is material liberation of the group (revolution), the actor and victim are viewed within the context of a combative

46. Today this philosophy is associated with many Black youths. "The same repugnant, essentially Victorian view of the inner-city [B]lack poor as incompetent and morally defective . . . suffuses the political discourse of the [B]lack petite [sic] bourgeoisie." Reed, False Profit-ll: All for One and None for All, NATION, Jan. 28, 1991, at 86, 90 (citing W. Wilson, The TRuly DisadVANTAGEd (1987) (noting "sharp increase in social pathologies in ghetto communities")).

47. E.g., the Ceniral Park rape.

48. E.g., the Howard Beach murder.

49. Mark Kelman's article, Interpretive Construction in the Substantive Criminal Law, 33 STAN. L. REV. 591 (1981), illustrates this process. Kelman argues that we employ conscious and unconscious constructs to expand or constrain our view of an event. See id. at 592-600. 
relationship. Yet, even as parochialism embraces the we/they construction, it is unable to resolve all of the resulting cases.

Under parochialism, it is meaningless, even comical, when "they do something to themselves." The parochialist is concerned with the community and its struggle against "them." When "they" destroy themselves, "they" aid the community's liberation. If the Howard Beach killers had murdered a white youth, a parochialist would not care. The oppressive society is considered inherently evil, abusive, and violent. When that violence is directed at the oppressive community's members, it is a deserved consequence of the oppressors' very nature.

The first situation, "One of us did something to one of them," is always justified because it is seen as a means of group liberation, an act of war against the oppressor. At the very least, it is a reaction to the violent oppression of the state. ${ }^{50}$ Conversely, in the second situation, "one of them did something to one of us," the act is always wrong and unjustifiable because it represents the oppression of the community. Here parochialism is most apparent.

The hard case for parochialism arises when "One of us does something to another one of us." Parochialists cannot decide to support either the actor or the victim because both are community members. Parochialism can initially justify the act (the murder) as the result of the historical oppression. A victim of that oppression, the actor isn't responsible for his actions. Ultimately, however, parochialism must also condemn the act as counterrevolutionary, an act of oppression itself. To this dilemma parochialism has no solution. Intracommunity violence is contrary to parochial liberation, but condemnation of the act of a community member would be contrary to parochialism's community unity ethic.

Parochialists construct acts broadly. Acts are tied to all the events of history that were ever oppressive. The actor is not only the perpetrator, but represents either (all of) the oppressed or oppressors. Parochialism is consciously deterministic in how it views acts. The Howard Beach murderers do not have any choice but to oppress and we can only expect the Central Park teenagers to lash out at oppression in an attempt to "liberate" themselves.

If parochialism condemns the actor in the "us versus us" case, it must necessarily discard its broad analytic frames. The only possible basis for that result is that it is wrong anytime any actor hurts someone. Thus the actor in the intracommunity murder is wrong and the Howard Beach killers are wrong, but so are the teenage rapists in Central Park. Parochialism starts to resemble

50. As such, a Black parochialist who sees white people as the oppressor is not sympathetic to the white woman raped and beaten in Central Park. The woman is an oppressor and it is her own fault as an oppressor that violence occurred. The oppressor created the conditions that produced the violence in the teenage rapists. Their actions are only attempts to liberate themselves or desperate attempts to lash out at the brutality of the oppressors. 
neo-liberalism..$^{51}$ Conversely, if parochialism condemns the victim, it must also discard its breadth. The "they versus us" act is no longer immoral or a sign of oppression. No acts are attacks on the community. The Howard Beach mob is no longer a demonic symbol of community oppression; it is simply a gang of murderers. As a result, parochialism reserves judgment on the "us versus us" act, ignoring community members victimized by fellow community members.

\section{Fatalism and the Just Act}

In the fatalist's view, destiny, the will of God or some other phenomenon beyond the control of man or the physical world is responsible for the oppressor's acts. Ultimately, neither the differential views of acts and actors nor manipulable analytic constructs illuminate this perspective, which transcends the physical world of acts and judgment.

Fatalism sees the oppressed group members as the "children of God." The price of disobedience is misfortune, and misfortune is the result of disobedience. ${ }^{52}$ Its assessment of acts is concerned primarily with the group members' relationship to God and ignores the actions of other people. ${ }^{53}$ Indeed, whenever a community member is victimized, it is necessarily either her own doing or a test of faith.

Furthermore, while particular fatalistic dogmas often present quite developed constructions of morality, fatalism is essentially amoral because it presents no particular construction of right or wrong for any given scenario. No act is necessarily just or unjust without a detailed dogma to guide moral thinking. Indeed, even while it attempts to incorporate the group's history of oppression into its view of acts, fatalism ignores oppression, relying on a higher order to eliminate exploitation.

\section{Neo-liberalism and the Just Act}

Neo-liberalism rejects the more insular views of parochialism and fatalism. Neo-liberals envision a world where "all [people] are created equal." An evil act occurs by definition whenever one person commits a violent act upon

51. See infra notes $37 \& 53-55$ and accompanying text.

52. Given particular dogmas such as destiny or God's will, the fatalist can resolve the four cases. The victim of intracommunity violence and the Howard Beach victim are dead because it was their destiny or the will of God. Either they were martyred for holy persistence or punished for some earthly evil in the face of earthly tribulations. Indeed, fatalism ignores the existence of an actor altogether, replacing the very real people who perpetuated the murders with abstractions. Just as intracommunity murderers and the Howard Beach lynchers are divested of volition, so are the rapists in Central Park. Their actions were destined or forced by God and their punishment will be similarly destined, indicating either continued oppression in an oppressive world, soldiers of God martyred in their incarceration, evil heathens abandoned by their God, or simply unfortunates at the peril of their destiny.

53. Fatalism, like parochialism, is wedded to the we/they construction of the world and thus ignores the victimization of the woman in Central Park as well as the Howard Beach perpetrators, casting them as faceless oppressors. Similarly, acts by oppressors against oppressors are ignored. 
another person. To neo-liberals, the identities of the actor and victim are unimportant. They reject the racial identification of victims and perpetrators implicit in the we/they construction in favor of a general theory that people as agents should be free from interference. The neo-liberal does not deny the existence of the we/they world. But the neo-liberal does assert that the we/they construction (oppression) exists because people are viewed and treated as victims and oppressors rather than equals.

When "one of us does something to one of them," we are evil because we inflicted harm upon another person. As community members we damage our own liberation by discounting the autonomy of others. Conversely, "they" are evil when they inflict harm upon one of "us." In the neo-liberal's quest for liberation, diminution of autonomy can never be justified by the we/they construction, as it was never justified under the oppression that created the we/they construction. When individual autonomy is compromised, the actor is always wrong and evil. It does not matter if we commit acts upon "ourselves" or they upon "themselves" since neo-liberalism sees one collective humanity. ${ }^{54}$

To incorporate its normative view of humanity, which rejects the subjective view of the historical construction of the community for either an objective view of humanity or a subjective view of dominant people, neo-liberalism employs narrow analytic constructs. The act is couched in a narrow time frame. It is viewed apart from other acts. The actor's intent is drawn narrowly to reflect only his desire to produce the result under consideration and not wide enough to include efforts at liberation or other motivations. ${ }^{55} \mathrm{Neo}$-liberalism's conception of a world of equal and undifferentiated humans prevents it from conceiving of the actors as anything but narrow, single individuals.

\section{Individualism and the Just Act}

Individualism's materialism makes its concept of autonomy different from neo-liberalism's by stressing personal success instead of humanity. Individualism emphasizes interpersonal relationships. It accepts that not all members of the group are concerned with the liberation of themselves or the community. It anticipates that some community members even reject the community and work against it. Individualism recognizes its own ethic: community members may aspire only for their own liberation, even at the expense of the community.

54. Here the killers in Howard Beach are as evil as the kids in Central Park. Furthermore, the victims are no more tragic because the killings are interracial or intergroup. Neo-liberalism emphasizes the victim and exalts life.

55. Neo-liberalism rejects determinism and focuses instead on individual will. Neo-liberalism considers rules-proscriptions designed for particular situations without exceptions-preferable to broad standards which leave room for tailoring to specific situations. See Kennedy, Form and Substance in Private Law Adjudication, 89 HARV. L. REV. 1685, 1687-1701 (1976) (discussion of relationship between rules and standards). 
Every act is judged by individual community members who claim to embody the community. Thus, the absolute justice of the act becomes indeterminable.

Like the varying dogmas of fatalism, ${ }^{56}$ the subjective determination of individualism is essentially amoral. The criteria for judging an act as justifiable is whether one individual "respected" another. However, to the individualist, respect is something to be demanded and is not given gratuitously. Individualism constructs a draconian, nihilistic world of "an eye for an eye" where the meek are trampled for their inability to assert dominion over themselves.

When anyone does anything to anyone else, the individualist asks, "who has been disrespected?" A community member, disrespected by the actions of another, is considered justified in avenging the initial transgression regardless of whether the offending person is cognizant of the offense. ${ }^{57}$ The state is treated as a pseudo-individual whose laws are respected only if they cannot be circumvented. ${ }^{58}$

Individualism espouses an "assumption of risk" doctrine. It does not matter whether an actor consciously disrespected someone, she is nevertheless responsible for the consequences of her actions. "Ignorance of the law" or ignorance of disrespect are unacceptable defenses because they destroy responsibility for actions and autonomy to act, central constructs of individualism.

No particular outcome is dictated by the we/they construction of life since the demands of respect for a given person are largely indeterminable. By and large, individualism breeds apathy to acts against other community members except to the extent that the acts affect oneself or to the extent the effect of those acts can be ascribed to oneself. ${ }^{59}$ Like fatalists, individualists ignore community member perpetrators, imputing disrespect by their victims. ${ }^{60}$ The we/they construction is only relevant to the individualist's views to the extent that oppressors, the lynchers in Howard Beach and the victim in Central Park, are largely ignored by the individualist. Individualists speculate about the community member's relationship with the oppressor. The Central Park rape

56. See text accompanying notes 51-54.

57. Such an analysis resembles an application of Malcolm X's contextual analysis-nonviolence for nonviolence and violence for violence as self-defense. Jones, Liberation Strategies in Black Theology: Mao, Martin, or Malcolm? in PHILOSOPHY BORN OF STRUGGLE, supra note 41, at 229, 232.

58. Malcolm X's pre-Islam view that "the only thing I considered wrong was what I got caught doing wrong" suggests that he viewed the law not as an abstract set of rights and wrongs but as a measure of the respect demanded by the pseudo-individual he considered the state.

59. Accordingly, the intracommunity murder is reprehensible to an individualist to the extent that some connection between the individualist and victim exists. Without a personal stake in the victim's life, the individualist adopts a result-oriented view that assumes the victim must have deserved his fate. The individualist would regard the Howard Beach victims in the same way.

60. The Central Park rapists are regarded similarly by the individualist. Barring some connection between the rapists and the individualist, the individualist is as likely to consider the rapists morally repugnant as not. The individualist is capable of assuming that rape might not be morally reprehensible because no abstract, objective "right" and "wrong" exists for the individualist. 
victim and the Howard Beach murders are deprived of their humanity; they are objectified as universal oppressors. ${ }^{61}$

Like fatalism, individualism simply manipulates narrow and broad analytical constructs to produce a favorable result as determined by the individual victim or actor's construction of justice.

\section{The Four Perspectives in the Jurispathic State}

Parochialism, fatalism, and neo-liberalism cannot survive as independent, comprehensive jurisprudential constructs in the jurispathic state. Parochialism fights a war that, by definition, it cannot win, destroying the community in the process. Fatalism creates martyrs, destroying the community's members physically or psychologically. ${ }^{62} \mathrm{Neo}$-liberals, while not destroyed by the jurispathic state, provide no realizable alternative, ignoring the community's problems. Thus, the community as a whole rejects neo-liberalism.

Individualism, presupposing no just order, focuses on the material improvement and autonomy of individuals. This narrow materialistic prescription bolsters individualism in a materialistic, jurispathic state. Individualism survives because it implicitly accepts the state's power and the ethic of individual material gain, even if it doubts the state's legitimacy. While least capable of developing a moral order, individualism becomes the perspective most likely to survive because it accepts oppression and the state and attempts to prosper within that context. Since individualism is amoral, a state's jurispathic tendencies tend to destroy structural morality in the oppressed community.

The jurispathic state effectively demands that an oppressed community overturn the state to develop a moral order that can thrive. The jurispathic state destroys, dismantles, and splinters the community, not only physically but also philosophically. The community's strongest and most viable perspective makes it necessarily subordinate to and dependent on the moral construction of the state that oppresses it. The community's only other alternative is to put forth inconsistent and contradictory combinations of views that, because of their inconsistencies, cannot resolve issues of relevance to the community satisfactorily.

61. Even as individualists ignore the oppressor, they are capable of justifying oppressor vengeance. Because individualists look at results, they necessarily embrace "might" over "right." Indeed, only might exists. Accordingly, individualists' reaction to the incarceration of the Central Park rapists assumes that the state has reason to incarcerate, torture, or even execute the rapists. The individualist would likely not even object to the murder of the rapists by their victim, even if she is an oppressor, because the rapists clearly violated-disrespected-her.

62. The spiritual demands of fatalist constructions, because their logical conclusion is martyrdom or suicide, force fatalists to adopt other perspectives to live in reality. The Nation of Islam, for example, is as much a parochialist and individualist sect as it is a fatalist one. $C f$. Reed, The Rise of Louis Farrakhan, THE NATION, Jan. 21, 1991, at 1: "[Farrakhan] has propagated a vision of political separatism and a program of moral rearmament, 'self-help' business development and an idiosyncratic brand of Islamic religion." (emphasis added). 


\section{APPLICATION TO CRITICAL RACE THEORISTS}

Critical race theorists have put forth complex, combined views of justice in the name of oppressed people that often obscure contrary views by other people of color. ${ }^{63}$ The following examination of writings by Professors Mari Matsuda and Richard Delgado illustrates this contention and shows how the inadequacy or complete lack of a conceptual model compromises their work. Section C suggests a method of avoiding the errors of Matsuda and Delgado.

\section{A. Quail Calls: Excluded Voices, Confused Voices}

Professor Matsuda makes several assertions about the value of the viewpoints of scholars of color: "This article . . . suggests a new epistemological source for critical scholars: the actual experience, history, culture, and intellectual tradition of people of color in America" and "those who have experienced discrimination speak with a special voice to which we should listen."64 Yet, she fails to explain what these statements mean. At one point Matsuda, apparently explaining the substantive value of her "excluded voices," says:

Outsider scholars have recognized that their specific experiences and histories are relevant to jurisprudential inquiry. They reject narrow evidentiary concepts of relevance and credibility. ... Not much time is wasted in those communities arguing over definitions of justice. Justice means children wi[th] full bellies sleeping in warm beds under clean sheets. Justice means no lynchings, no rapes. . . . It means control over one's own body. These kinds of concrete and substantive visions of justice flow naturally from the experience of oppression. ${ }^{65}$

While I accept Matsuda's contention that scholars' (and people's) histories are relevant to jurisprudential inquiry and the construction of definitions of justice, her conclusions following this contention are inconsistent and sometimes wrong. Her statement implies a parochialist model for people of color, but then fails to account for its own divergent perspectives, contradicting itself and excluding divergent views. Matsuda's characterization implies uniformity of belief. People of color are depicted as a cohesive, monolithic entity with a singular, logically consistent, and inherently valuable view of moral right developed via the state of oppression. The scholars of color seem unified and undistinguishable, amassed and ready to assail the oppressor. ${ }^{66}$ Whereas Ran-

63. See supra, text accompanying notes 10-13; see also Kennedy, supra note 2, at 1784 (criticizing Matsuda as having "a tendency to repress the diversity of ways in which similarly situated people conceptualize the world.").

64. Matsuda, supra note 10 , at 325,324 .

65. Matsuda, supra note 6 , at 8 .

66. Of course, a parochialist-like characterization among scholars of color is not new. See Fontaine, Social Determinism in the Writings of Negro Scholars, 49 AM. J. Soc. 302 (1944) (work of Black scholars 
dall Kennedy argues that Matsuda stereotypes scholars via "the perceived characteristics of the racial group with which the individual is associated,"67 Matsuda's characterization also stereotypes scholars via the parochialist perspective inherent in her implicit definition of community.

Notwithstanding the apparent similarity between parochialism and Matsuda's characterization of people of color's views, her characterization presents several substantive views which are inconsistent with parochialism. She assumes parochialism's construction of acts when she states, "[Outsider scholars] reject narrow evidentiary concepts of relevance and credibility." This construction partially excludes fatalism and individualism which use both narrow and wide evidentiary concepts. And she completely excludes neo-liberalism which rejects altogether wide evidentiary constructions.

However, Matsuda's characterization abandons parochialism in its claim that oppressed people necessarily condemn rape and lynching. Even if the oppressed community is defined to include women generally (as opposed to only women of color), Matsuda's work does not reflect upon why parochialists would necessarily object to rape since parochialists cannot resolve intercommunity crime. Nor does Matsuda suggest why a community influenced by parochialism would object to raping oppressors (women or men) ${ }^{68}$ Furthermore, Matsuda does not recognize that individualists might sanction a lynching or rape, even intercommunity lynchings or rapes, given certain constructions of respect.

When Matsuda asserts that oppressed people want control over their bodies, can she deny that fatalism discounts the importance of control over one's body, or that parochialism emphasizes group over individual or personal autonomy, or that, even as individualism seeks such autonomy, it rejects the notion that control over the body is ever possible?

More likely Matsuda is making a normative statement about her preference for the program she outlines. If that is the case, through her formulation of a contradictory and exclusionary jurisprudence, she has in effect destroyed her initial argument that there are important views that attach to being oppressed. She mischaracterizes people of color most when she casually asserts in the passage that "not much time is wasted in those communities arguing over definitions of justice." The very premise of this Note is that oppressed communities have four, not one, competing conceptions of justice. While babies with full bellies may be an important concern of some community members, they

often more a defense of race than quest for truth).

67. Kennedy, stupra note 2, at 1787.

68. Former Black Panther Eldridge Cleaver once advocated the rape of white women as a means of achieving liberation (and also advocated the rape of Black women for "practice"). While he later retreated from this belief he described it as prevalent among many Black males. E. CLEAVER, SOUL ON ICE 13-17 (1968). If Cleaver is an anomaly and his descriptions inaccurate, it is still true that women of color are more frequently victims of rape than white women. $C f$. Johnson, On the Prevalence of Rape in the United States, 6 SIGNS 136, 142-43 (1980) (estimates based largely on statistics relevant to nonwhite populations); Gollin, Comment on Johnson's "On the Prevalence of Rape in the United States," 6 SIGNS 346, 347 (1980) ("What is chilling in these data are the consistently greater risks for non-white women ... ..) (emphasis in original). 
quite frankly are not as important to others, depending upon the perspective influencing a person's view of life, liberation, and justice.

Matsuda fails to outline why her combination attaches to oppression rather than sheer preference. Her characterization takes the form of an empirical statement, but comes with no proof. In the end, people of color who disagree with her construction are marginalized much more than if they were excluded by the oppressor since Matsuda claims that oppressed people, by definition, will agree with her vision of justice.

\section{B. Delgado: Racism and the Paternal State}

Richard Delgado also asserts the academic value of listening to people of color. ${ }^{69}$ In his critique of CLS, Delgado suggests that minorities have problems with CLS's rejection of rights theory and its utopian vision. He then outlines what he believes minorities seek in a legal theory. ${ }^{70}$

Like Matsuda's characterization of people of color, Delgado's critique of CLS appears to begin from a parochialist perspective. However, the substance of Delgado's critique seems to embrace several perspectives as it moves from a discussion of rights discourse to a critique of utopian vision. Civil rights law may have given scholars of color an affinity for rights discourse. However, it is one thing to say that minorities want to use rights theory because in current legal discourse it is a means of limited liberation ${ }^{71}$ (a perfect individualist view) and yet another to suggest that minorities are so fond of it that they would not replace it if they could.

Rights discourse is inconsistent with parochialism. Rights discourse assumes that community members are due a certain kind of treatment either because the state draws legitimacy as a representative of all its citizens or because the state is bound to act in accordance with certain universal or objective principles. In either case parochialists reject rights discourse as promoting "false consciousness" by misleading community members into believing that justice flows from the state or universalism, instead of the community. Of course this mirrors CLS's evaluation of the legal system's relationship with the oppressed.

While instrumental rights are consistent with individualism, rights-based legalism is mandated by neo-liberalism, premised as it is on the concept of abstract or natural rights. Delgado says that minorities are against CLS's rejection of rights-oriented legalism. But while he appears to say this is because

69. Delgado, When a Story Is Just a Story: Does Voice Really Matter?, 76 VA. L. REV. 95,98 (1990) ("IA]ll people of color speak from a base of experience that in our society is deeply structured by racism. That structure gives their stories a commonality warranting the term 'voice.' ") (footnote omitted); see also Delgado, supra note 7.

70. Delgado, The Ethereal Scholar: Does Critical Legal Studies Have What Minorities Want?, 22 HARV. C.R.-C.L. L. REV. 301, 306, 309, 320-21 (1987).

71. See Williams, Alchemical Notes: Reconstructing Ideals from Deconstructed Rights, 22 HARV. C.R.C.L. L. REV. 401, 403-05 (1987). 
the CLS critique removes the only means of liberation in a racist society, it is not clear whether he argues for either instrumental or abstract rights. Without a framework, he does not recognize any significant difference.

Even though all of the community's pure perspectives are utopian, parochialism and individualism are rooted in material reality. The CLS utopian vision is more like a fatalist view premised on brotherly love and altruism. The utopian nature of the CLS program is then abstract and inconsistent with parochialism and individualism which decry abstract liberation.

It might have been more valuable for Delgado, with a less stereotyped conception of minorities, to note the inconsistency between the rejection of rights that parochialism espouses and the utopian vision of CLS that resembles closely fatalist and neo-liberal visions. By embracing a vision of minorities that conflates parochial and neo-liberal perspectives, Delgado calls both wrong without noticing how awkward (if not incompatible) the anti-rights views and utopian visions of CLS are when taken together.

More frightening because it implies uniformity of belief, however, is Delgado's evaluation of what minorities want. First, he says they want an end to racism. From this conclusion he claims minorities want a formal, structured society with a proactive program against racism. ${ }^{72}$ However, individualism does not much care for an authoritative state nor is it much concerned with racism except to the extent that it constitutes stereotyping and disrespect of the individual's autonomy. Parochialism is only sympathetic to such a state if minorities are in charge.

Nowhere is it clear why minorities want a state with countercoercive structures designed to promote minority well-being. ${ }^{73}$ Such may be what minorities need, but given the community's divergent views, it is necessary for Delgado to express why such a program is mandated. Failing to do so he marginalizes those minorities who possess divergent views.

\section{Escaping the Errors: One Route}

One way to escape the errors made in the Matsuda and Delgado selections is to employ what Gerald Torres has called "conversation ending moves,"74 stories in the first person. Professor Patricia Williams' Spirit Murdering the Messenger ${ }^{75}$ successfully employs this technique. By using the personal voice in her opening story Williams outlines a view she seems to accept, narrows that view, and avoids ascribing that view to other community members while

72. Delgado, supra note 70 , at 320,321 .

73. Id.

74. Address by Professor Gerald Torres, Yale Law School, James A. Thomas Lecture (Apr. 5, 1990).

75. Williams, supra note 21. 
simultaneously implicating the relevance of the view to the larger community. $^{76}$

The invocation of a narrative in the personal voice does not automatically evade the problems outlined in the Matsuda and Delgado pieces; however, it does clearly attach the ideas to the writer and to all those who affirmatively profess their agreement with her. Narratives in the personal voice are inconsistent with parochialist and fatalist constructions. The use of the personal voice to express a parochial or fatalist view forces speakers to claim to speak for others when they very often have no authority ${ }^{77}$ to do so. This is because parochial and fatalist constructions minimize the significance of individuals' opinions relative to group opinions. Conversely, individualism and neo-liberalism demand deference to the individual's view.

When a writer advocates a variation of either individualism or neo-liberalism, a personal story is often enough to establish the author's position. The story in this context gives the reader the authority to determine the significance of the story based on both the reader's view of right and the account of the writer. ${ }^{78}$ The writer can argue that her experience mirrors that of other people, but the experience is forever associated with the author.

When the writer espouses a parochial position, the distance between the writer and the community is great and the connection unclear. Since the origin of the writer's authority is not apparent, the author's claim is immediately suspect. Absent political or institutional authority the writer must prove that what she says a community believes is in fact true. Without such proof, the writer is left to rely on the chance that her assertions mirror popular views.

\section{CONCLUSION}

Paul Brest argues that scholars, lawyers, and judges, because of their class and education, have a tendency to agree with libertarian views much more than

76. In the story she relates in the first part of her article Williams is angered when she is excluded from a shop because it deprives her of individualism and the respect and dignity associated with it. She is offended not only because her exclusion was obviously unwarranted, but also because she personifies the community she identifies (and is identified) with. She knows some Black people would be let in; but more importantly, she knows that others like her will be locked out. Williams, supra note 21 , at 127 .

She calls for the recognition of the individual's autonomy as a human being who is also oppresseda call for respect. Elsewhere, Williams notes that for slaves, sharecroppers, and prisoners, poverty and need deprived them of their individualism, casting them as mere universal abstractions of man. For these people she argues that rights imply respect and create a complete social being. Williams, supra note 71 , at 416 .

77. By authority I mean political authority derived from a legitimate political process (e.g., election or appointment), institutional authority derived from a social position or status, academic authority found in primary or secondary support (e.g., empirical data, statistical studies, or abstract theories), or popular authority found when a speaker says what all or most members of the relevant community acknowledge to be true. The statements of Matsuda and Delgado, which are parochial in some respects, seem to rely primarily on popular authority, the legitimacy of which is questionable and largely fortuitous.

78. Delgado notes in his Plea for Narrative, "Stories and counterstories, to be effective, must be or must appear to be noncoercive. They invite the reader to suspend judgment, listen for their point or message, and then decide what measure of truth they contain." Delgado, A Plea For Narrative, supra note 9, at 2415. 
a sample of the mass public. ${ }^{79}$ If Matsuda and Delgado belong to Brest's class of opinion and legal elites, their views can be expected to diverge from the views of a "mass public" segment of the community of color and are reduced to personal statements.

Specifically, I believe Matsuda and Delgado err in two ways. First, they compromise the views of the people of color they claim to represent by not acknowledging divergent views. They fail to recognize the components of their own views of justice and how their views differ from divergent views in the community for which they claim to speak.$^{80}$ Second, they compromise their scholarship. If scholarship is a quest for "truth," Matsuda and Delgado fail by excluding divergent minority voices without justification.

More generally, because they fail to acknowledge that people of color embrace a diversity of jurisprudential perspectives which can enrich legal discourse, Matsuda and Delgado defeat their own premise that minority views are valuable. They forget that there is reason to articulate and include the voices of the excluded even if the excluded are no longer oppressed. Indeed, the very existence of a jurisprudential perspective among oppressed people is compromised by the monolithic definition of community resulting from to the lack of a conceptual model.

The fact that Blacks were enslaved does not by itself dictate how a descendant of slaves will view a particular act. It is the examination of the less abstract, that element which lies between the historical constructions and their ultimate conceptual conclusions (the four perspectives), that produces substantive answers to moral questions. Yet the critical race theorists examined here seem to suggest that substantive answers flow from the definition of the community (e.g., a person's status as a descendent of slaves). Two of the perspectives, the neo-liberal and individualist, even reject the community's significance as a tool of liberation, calling community definition into question.

Oppressed people do not need legal commentators or a conceptual model to make moral decisions. However, understanding the implications of moral decisions requires both a framework connected to the historical construction that defines the community as oppressed and a familiarity with that history. The model presented in this Note can be used to categorize and understand moral visions and actions. While it suggests that certain perspectives cannot answer certain questions, it does not dictate how moral questions should be answered. For example, it does not suggest what dogma might arise in a fatalist universe. The model simply categorizes reactions to oppression and suggests the form each reaction's view of justice would take.

79. Brest, Who Decides?, 58 S. CAL. L. REv. 661, 665 (1985).

80. To say scholarship must accurately portray a community does not mean it must be all-inclusive; however, no scholarship should be confusing, unclear, or politically motivated. 